\title{
Science Requires Coexisting of Opposite Opinions:“One Country, Two Systems"
}

Lee Jia*

Cancer Metastasis Alert \& Prevention Center, Fuzhou University, Fuzhou 350002, China

\section{Editorial}

Following the returning of Hong Kong and Macao to China, China is persuading Taiwan to join its special administrative region marked "one country, two systems", a famous political policy announced by Chinese late-leader Deng Xiaoping. Politics, which addresses the complex problem of reconciling human aspirations, is a specific subject that is generally applied to the art or science of running governmental or state affairs, including behavior within civil governments, but also applies to institutions, fields, and special interest groups.

In science, as in politics, those in authority have an interest in the current orthodoxy. Left to them, it is altogether conceivable that the scientific leadership, like the political leadership, might place obstacles in the path of change in political and economic reform. However, the democratic structure in science prevents this. Under democracy, each new orthodoxy has its opportunity to persuade the people and later, to be modified by the people.

It should be recognized that science constitutes one of democratic organizations. It is a subtle structure in which the dominant views establish themselves in forums organized to give a hearing to disagreement. These views prevail because of their power to persuade, and not because of the power of those who hold them.

Any sufficiently advanced technology is indistinguishable from magic thinking that should be protected by democracy. Scientific policy should encourage creative thinking and formulate visionary ideas with a wide range of predictions that may become reality in the future. Such policy should encourage thinking outside of the box, generating new scientific paradigms, or disrupting the old ones. As a result, it will liberate young scientists to incubate extraordinary ideas and approaches.

Today, China is shifting away from raw materials and manufactured goods to information economy. The past few years have witnessed that the numbers of scientific publications coming from China rose to thousands per year, next to the United States [1]. There are several sources of funding for new technology in China, including the National High Tech R\&D Program of China, the National Natural Science Foundation, the Ministry of Science and Technology and the Chinese Academy of Science. The method of gaining funding from the government has been recently adopted in China to allow start-up companies to apply for grants. The country now has its own smallbusiness innovation research program, called the Innovation Fund for Small Technology-Based Firms. The high numbers of papers presented at recent scientific conferences in China provides evidence of the significant amount of research and development that is being carried out by Chinese researchers. The Chinese patent office is now flooded with applications that are relevant to new technology. Recent enforcement of intellectual-property rights since China joined the World Trade Organization has led to greater respect for patents in China and has improved the country's investment climate. Of particular interest to us is to improve the nation's standardization, modernization, and internationalization.

Science presents the same scene of waste as does commerce. But having wrong ideas, as we often do, is a necessary part of the process of having right ones. Science, like commerce, is an organic process in which the interaction of the parts must be permitted to produce unpredictable outcomes. If science, or commerce, or politics, is to flourish, we must build into them sufficient freedom that they can surprise us.

As scientists we are required to defend our views in public. There are many ways of structuring a democratic system, but there is no way of sustaining one without vigilance to ensure that minority views are heard in order to be judged. As scientists we share the belief that freedom of thought and expression are vital to achieving new insights. One country, two systems is a motto we can embrace when it becomes an invitation to openness and tolerance.

\section{References}

1. Jia L, Zhao Y, Liang XJ (2011) Fast Evolving Nanotechnology and Relevant Programs and Entities in China. Nano Today 6: 6-11.
*Corresponding author: Lee Jia, Cancer Metastasis Alert \& Prevention Center Fuzhou University, Fuzhou 350002, China; Email: pharmlink@gmail.com

Received October 13, 2012; Accepted October 15 2012; Published October 17 2012

Citation: Jia L (2012) Science Requires Coexisting of Opposite Opinions:"One Country, Two Systems". Pharmaceut Reg Affairs 1:e114. doi:10.4172/21677689.1000e114

Copyright: (C) 2012 Jia L. This is an open-access article distributed under the terms of the Creative Commons Attribution License, which permits unrestricted use, distribution, and reproduction in any medium, provided the original author and source are credited. 